\title{
1968: A THEMATIC INQUIRY
}

Chad Kuehnl

Fieldcrest High School

Minonk, Illinois
Teaching History 46(2)

DOI: $10.33043 /$ TH.46.2.35-40

(C) 2021 Kuehnl.

Distributed with CC BY-NC-ND 4.0 License.

In the study of United States history, many iconic years have come to define America. In recent years, several thematic based projects have attempted to use these years to reshape the American narrative. The 1619 Project, developed by Nikole Hannah-Jones and the New York Times has called for Americans to "reframe the country's history by placing the consequences of slavery and the contributions of black Americans at the very center of our national narrative." "The conservative response by the Trump Administration led to The 1776 Report as a way to promote patriotic education by "cultivating a better education among Americans in the principles and history of our nation." ${ }^{2}$ Other years such as 1877, which brought about the end of Reconstruction, are also gaining attention in light of recent events. Decades of police brutality aimed at African Americans, highlighted in part with the murders of George Floyd and Breanna Taylor, have shown that the failure to protect Reconstruction's goals and defend African Americans from racial terror have created many of the issues that we deal with today. While the previously mentioned years are deserving of academic study, the year 1968 demands our attention as a way to understand present day America. The aim of this article is to promote a thematic unit of study of the year 1968 and its connections to the present day by investigating themes such as national identity, domestic politics, and foreign affairs. Students will then be able to consider the direct impact of 1968 on our current political and cultural climate as well as the impact on their lives.

\section{Rationale for 1968 as a Theme for United States History}

The year 1968 has come to represent the larger themes in U.S. History that have shaped the nation's narrative including struggles for racial and gender equality, protest movements, and the impact of war on American society. At bare minimum, 1968 represents a tumultuous time in United States history that was the culmination of two decades of domestic and foreign challenges. At its most extreme, the United States of 1968 was, in the words of Eldridge Cleaver, shaping the "destiny of the entire human race."

The continual fight for racial equality is quite visible in 1968. Events such as the Howard University protests, which called for an implementation of black studies and reforms at the institutional level, highlight 1968 as a year in which a black consciousness was being raised. This fits into the larger theme of tackling American racism while demonstrating the nuances in the aims of the Civil Rights Movements' activists. In this moment, African American students fought to elevate the racial narrative within American institutions as opposed to the centuries long battle for inclusion into the institutions themselves.

The ongoing battle for gender equality in the American narrative reached new levels with the shift of the feminist movement in 1968. With the phrase, "the personal is political," radical feminist Carol Hanisch and other women from across the nation tackled "antiquated, misogynistic attitudes toward women and beauty, but also to how the United States, as a whole, treated women." 4 This culminated with a march against the 1968 Miss America pageant that brought about a new wave in feminism. This moment in 1968 is symbolic of the large theme of activism toward gender equality as it can be traced to earlier generations of women's fight for a place in the democratic system. The activism of 1968 is still present in equality movements of today. Marches such as the 2017 Women's March on Washington, which was held in response to President Donald Trump's "misogynistic"

\footnotetext{
${ }^{1}$ Nikole Hannah-Jones, "The 1619 Project," The New York Times Magazine, August 14, 2019, https:/www.nytimes.com/ interactive/2019/08/14/magazine/1619-america-slavery.html

${ }^{2}$ The President's Advisory 1776 Commission, "The 1776 Report," January 2021.

${ }^{3}$ Eldridge Cleaver, Soul on Ice (New York: McGraw-Hill Book Company, 1968).

${ }^{4}$ Roxane Gay, "Fifty Years Ago, Protesters Took on the Miss America Pageant and Electrified the Feminist Movement," Smithsonian Magazine (January/February 2018), https://www.smithsonianmag.com/history/fifty-years-ago-protestors-took-onmiss-america-pageant-electrified-feminist-movement-180967504/
} 
comments and remarks that attacked "people of color, immigrants, and the LGBTQ+ community," demonstrates 1968's place in the larger theme of the American struggle for equality. ${ }^{5}$

The year 1968 also claims one of the most iconic moments regarding the theme of war and protest in the American narrative. While many U.S. wars had their dissenting moments, few had the long-term impact of the protests at the 1968 Democratic Convention in Chicago, Illinois. Spurned in part by disagreement over the Vietnam War, especially after the Tet Offensive earlier in the year, "many people began to believe that the U.S. government was no longer a democracy, but had become an illegitimate institution led by 'war criminals' and enforced by 'the pigs."'6 This belief led to clashes between protestors and Chicago Police officers and the Illinois National Guard. Protestors shouted, "The whole world is watching, the whole world is watching!" Unfortunately for the protestors, Americans did not respond in the way the protestors had hoped they would. America elected Nixon under a law-and-order campaign, and the Vietnam War continued. Americans continued to protest and by 2014, in the context of protests in Ferguson, Missouri over the fatal police shooting of unarmed African American teenager Michael Brown, the world of today not only responded but reacted in ways not available in 1968. With the rise of social media, protesters from all over the globe tweeted advice to Ferguson about how to deal with a militarized police force. With live stream technology that can circumvent mainstream media, "Ferguson is a good reminder that when the whole world watches now, it is looking through a seemingly infinite number of lenses." This technological evolution in American protest was magnified with the sentencing of Minneapolis officer Derek Chauvin after the murder of George Floyd in 2020. Darnella Frazier, who recorded Floyd's murder, would receive praise for her "bravery and quick thinking in capturing the video that they say made the guilty verdict possible."8

1968 can undoubtedly be seen as a year that speaks about our American themes as whole. When reflecting on the year 1968, Time magazine commented that "historians' turning-point years involve wars and revolutions, not peaceful change. Clearly, 1968 is already a year for the history books; if it becomes a really major entry, the reason will be that Americans failed to solve too many of the minor problems that eventually cause major explosions." This quote is central to why 1968 is emblematic of the themes in American history. By studying the themes of America through the year 1968, students can see how the bigger themes of race, gender, war, and conflict are reflected in our nation today as they to fight to solve America's generational and ongoing thematic issues.

\section{8 to Today - A Thematic Inquiry}

Through a thematic inquiry into major events of 1968, students will answer the following major question: What does 1968 mean to the creation of the current American identity? The 1968 theme will have three subtopics of study which promote exploration into the people and events that shaped the year 1968. A final open-ended document based summative assessment will allow the students to demonstrate how they see connections and differences between 1968 and our current American identity.

\footnotetext{
${ }^{5}$ National Museum of American History, “The Women's March, 2017,” https://americanhistory.si.edu/creating-icons/ women $\%$ E2\%80\%99s-march-2017

${ }^{6}$ Terry M. Anderson, "1968: The End and the Beginning in the United States and Western Europe," South Central Review 16/17 (1999), 12.

${ }^{7}$ Robyn Urback, "Ferguson Authorities Don't Have a Monopoly on Information. The Sooner They Realize That, The Better," August 18, 2014, https://nationalpost.com/opinion/robyn-urback-ferguson-authorities-dont-have-a-monopoly-on-information-thesooner-they-realize-that-the-better

${ }^{8}$ Rachel Treisman, “Darnella Frazier, Teen Who Filmed Floyd's Murder, Praised for Making Verdict Possible,” April 21, 2021, https:/www.npr.org/sections/trial-over-killing-of-george-floyd/2021/04/21/989480867/darnella-frazier-teen-who-filmed-floydsmurder-praised-for-making-verdict-possib

9 "What a Year!" Time, August 30, 1968.
} 
National Identity and the Struggle for Equality

In this subtopic, the students will answer the following question: Are major events in the struggle for equality from the year 1968 mirrored in our society's activism today? In 1968, support for the Civil Rights Movement was dwindling, and the murder of Dr. Martin Luther King, Jr. also hampered the movement. Still, the struggle for racial equality moved forward. One of the most monumental moments was the Poor People's Campaign, which was meant to be "a new co-operation, understanding, and a determination by poor people of all colors and backgrounds to assert and win their right to a decent life and respect for their culture and dignity." ${ }^{10}$ While the campaign's goals were not fully achieved, the aims of the campaign "remain the most visionary and brilliant strategy to overcome poverty ever put forth in our nation." ${ }^{11}$ This campaign has had a revival in 2021 with a new march calling on Americans to "resist the extremist and monied powers that want to deny, abridge, and undermine all of our votes." 12 By examining these two versions of the Poor People's campaign, students can examine the relevance of this campaign both in 1968 and today and reflect on their commonality.

One of the more successful movements of 1968 came from Latino high school students in East Los Angeles who walked out of their classrooms to address racism. Student demands for educational reform included increases in school funding and more attention to Mexican history and culture. The long-term results of the walkouts led to an increase in Mexican American teachers and administrators coupled with an increase in Latino enrollment in higher learning institutions throughout the 1970's. By having students explore the legacy of these walkouts, they will appreciate their own generation's student activism. This is especially true regarding the March for our Lives campaign, led in part by student activist X Gonzalez (born Emma Gonzalez), who marched to pressure lawmakers to address gun violence and support gun control legislation in the aftermath of the Marjory Stoneman Douglas High School shooting in 2018. The fact that activists in both events are of the same age as the students will help further a connection to the people and causes that were being fought for in 1968 and today.

Gains were also being made on gender frontiers. Shirley Chisholm became the first black woman elected to the U.S. House of Representatives. In 1968, five thousand women took part in the Jeannette Rankin Brigade March, led by the 87-year-old congresswoman herself, to protest the Vietnam War. It has been reported that the slogan, "Sisterhood is Powerful," was coined by Kathie Sarahchild at this march, pushing forward the feminist movement into the 1970's and beyond. The impact of the movement has permeated into 21st century activism with Tarana Burke's \#MeToo Movement whose goals include "healing through engagement in community organizing, where survivors are empowered to fight sexual violence with courage and conviction." ${ }^{3}$ Students will be able to connect the impact of women's activism of 1968 with the 21 st century movements toward gender equality.

\section{Domestic Political \& Economic Issues}

In this subtopic, students will be answering the following question: Are major political and economic moments from 1968 still shaping U.S. politics and social issues today? By utilizing their own familiarity with the recent 2020 election, students will see how public opinion can impact the political actions of Presidential candidates and even reshape the political direction of a nation. Students will also explore differences between the economic issues of 1968 and the present day and their impact on society.

Two months before the assassination of Dr. Martin Luther King, Jr., the Kerner Commission, sponsored

\footnotetext{
${ }^{10}$ Southern Christian Leadership Conference, Press release, "Black and White Together," March 15, 1968.

${ }^{11}$ Terry Messman, “The Poor People's Campaign: Non-Violent Insurrection for Economic Justice," Race, Poverty \& the

Environment 14, no. 1 (2007), 30.

12 "Poor People's Campaign Embarks on 4-day, 27-mile "Moral March" for Democracy in Texas," The Black Wall Street Times, July 27, 2021, https://theblackwallsttimes.com/2021/07/27/poor-peoples-campaign-embarks-on-4-day-27-mile-moral-march-fordemocracy-in-texas/

13 “Vision \& Theory of Change," https://metoomvmt.org/get-to-know-us/vision-theory-of-change/
} 
by President Lyndon B. Johnson and led by Governor Otto Kerner Jr. of Illinois, declared that the nation was "moving toward two societies, one black, one white-separate and unequal." ${ }^{4}$ The Johnson administration failed to react to this prophetic statement, and later that year Richard Nixon used a law-and-order campaign to win the presidency. The legacy of this missed opportunity to address racial inequality can still be seen today. For example, the aims of the Black Lives Matter movement include addressing persistent racism, discrimination, and inequality experienced by African Americans. President Donald Trump's reactions in 2020 were dismissive and counter-reactionary. Trump himself tweeted that a proposed BLM sign on New York's Fifth Avenue was a "symbol of hate." 15

Students can also explore the 1968 election itself to examine how the platform shifts of both parties that took place during the election still impact the political platforms today. Democratic nominee Hubert H. Humphrey's loss paved the way for a party split. This split eventually moved the Democratic party to embrace "a more liberal foreign policy perspective and a greater appreciation for social justice issues." Republican Richard Nixon's initial use of the Southern Strategy, to gain the votes of individuals who opposed school desegregation and the votes of northern whites, still resonates on the direct impact of our political parties' platforms today. Trump would also apply tactics used by Nixon when stoking fears of racial integration. During the 2020 Presidential campaign, Trump made the statement that he was "happy to inform all of the people living their Suburban Lifestyle Dream that you will no longer be bothered or financially hurt by having low-income housing built in your neighborhood." 16 This appeal to white conservative suburban voters was another attempt to flame decades old fears of poor Blacks flooding into white neighborhoods. With a comparison of 1968 to today regarding domestic policy, students are given the opportunity to inquire on how much we shape the political agenda or how much the political agenda shapes our thinking on political and social issues.

This 1968 thematic unit can also explore stark differences from the present day. In 1968, wages were rising, and unemployment was dropping. In December 1968, Time magazine noted that "the median income of a U.S. family of four has risen fifty-four percent" while "unemployment has dropped to a fifteen-year low of three point three percent." ${ }^{17}$ Overall, numbers have remained consistent with the numbers from 1968. Even with an ongoing pandemic, the U.S. unemployment rate was at just over five percent as of July 2021. ${ }^{18}$ The median income of 2021 was at $\$ 79,900$ as of April $2021 .{ }^{19}$ However, when minimum wages and racial inequality are compared from 1968 to today, the numbers reveal a more concerning and different picture. The minimum wage of 1968 was $\$ 1.60$, or $\$ 12.90$ in today's dollars. The federal minimum wage has remained at $\$ 7.25$ an hour since 2009 , exacerbating America's ongoing wage inequality over the last decade. According to the Brookings Institute, "forty-four percent of U.S. families in 2019 did not earn an income that was high enough to cover their families' living expenses." ${ }^{20}$ When race is factored in, the numbers become more alarming. When looking at 1968 and present-day median family income, "African American family income was fifty-seven percent of the median white American family income. In 2016, the ratio was fifty-six percent." ${ }^{21}$ In April 2020, with the pandemic

\footnotetext{
${ }^{14}$ National Advisory Commission on Civil Disorders, "Report of the National Advisory Commission on Civil Disorders: Summary of Report," (United States: Government Printing Office, 1968), 1.

15 “President Trump Calls Proposed Black Lives Matter 'Sign' in NYC 'Symbol of Hate,"' https://abc7ny.com/black-lives-mattersymbol-of-hate-mural-in-nyc-trump-calls-a-fifth-avenue/6288343/

16 “Trump Stokes Racist Fears After Revoking Obama-Era Housing Rule Intended to Fight Segregation,” https://abcnews.go.com/ Politics/trump-stokes-racist-fears-revoking-obama-era-housing/story?id=72074862

17 "The Economy in 1968: An Expansion That Would Not Quit," Time, December 27, 1968.

${ }^{18}$ Bureau of Labor Statistics, U.S. Department of Labor, 2021, https://www.bls.gov/news.release/pdf/empsit.pdf

${ }^{19}$ U. S. Department of Housing and Urban Development, 2021, https://www.huduser.gov/portal/datasets/il/il21/HUD-sec236-2021. pdf

${ }^{20}$ Sifan Liu and Joseph Parilla, "How Family Sustaining Jobs Can Power an Inclusive Recovery in America's Cities," Brookings, February 18, 2021, https://www.brookings.edu/essay/how-family-sustaining-jobs-can-power-an-inclusive-recovery-in-americascities/

${ }^{21}$ Robert Manduca, "Income Inequality and the Persistence of Racial Economic Disparities," Sociological Science 5 (2018), 182.
} 
raging, less than half of African Americans adults were employed. ${ }^{22}$ By focusing on the economic differences between 1968 and the present day, students will see how the nation has struggled to meet the needs of lowincome families for decades. Students can also explore how 1968's economic issues such as "growth-inducing tax cuts, an escalating war in Vietnam, and increased social spending at home had overstrained economic institutions and capabilities" crippling President Johnson's Great Society programs and impacting American minorities' financial standing up through the present day.

\section{Foreign Affairs}

Students can also explore foreign affairs of 1968 and today and investigate connections and differences. Student familiarity with recent issues such as immigration, the war in Afghanistan, and the COVID-19 pandemic, will help to guide the students' focus with the following subtopic question: Are responses to foreign affairs from 1968 still shaping how we respond to foreign affairs today? Foreign affairs and the election of 1968 echo today as "few elections in U.S. history were so dominated by foreign policy and few elections so affected foreign policy during a campaign." ${ }^{23}$ Both campaigns had to convince voters that they would bring peace by ending the Vietnam War. This was driven by Walter Cronkite's negative critique of the war's progress, especially after the Tet Offensive, which exposed Johnson's false claims that the U.S. was winning. Nixon had "managed to combine peace with toughness without exactly saying how he would bring peace or where he would get tough," demonstrating to the public that his path was vastly different than the path Johnson was taking and that a Democratic successor of Johnson would presumably follow. ${ }^{24}$ This strategy can be seen as well in the words of Donald Trump during his 2016 bid for the presidency. As early as June 2015, Trump commented that he "will build a great, great wall on our southern border, and I will make Mexico pay for that wall. Mark my words." 25 Trump took a play from the Nixon campaign to look tough on a foreign affairs issue without laying out a detailed plan. Students can compare these responses to foreign affairs and consider how our politicians have or have not changed in responding to calls for action by the general public.

The Vietnam War can be used to distinguish differences from 1968 and today. As the media exposed the reality of the Vietnam War, support began to wane. At the beginning of the year, polling "showed that about fiftythree percent of the public supported the war. By the end of the year, fifty-eight percent opposed it." ${ }^{26}$ In regard to the war in Afghanistan, "Gallup surveys tracking Americans' perceptions of previous wars, including Iraq, Vietnam, and Korea, have found majorities at some point describing those efforts as a mistake, something that has not occurred with respect to Afghanistan." ${ }^{27}$ Students can explore why this two decade long conflict never had the same resentment that the Vietnam War had against it even though only "twenty percent of U.S. adults say they trust the government in Washington to "do the right thing" just about always or most of the time. ${ }^{28}$ As students are often engulfed in social media on a continual basis, an inquiry can be made on the reaction to media and warfare. While today's youth have always had the ups and downs of the war in Afghanistan illustrated

\footnotetext{
${ }^{22}$ Heather Long and Andrew Van Dam, "The Black-White Economic Divide is as Wide as It Was in 1968," The Washington Post, June 4, 2020, https://www.washingtonpost.com/business/2020/06/04/economic-divide-black-households/

${ }^{23}$ Melvin Small, “The Election of 1968," Diplomatic History 28, no. 4 (September 2004), 528.

${ }^{24}$ Nelson W. Polsby, Presidential Elections, 5th ed. (New York: Scribner's, 1980), 174.

${ }^{25}$ Glenn Kessler, "A History of Trump's Promises that Mexico Would Pay for the Wall, Which It Refuses to Do," The Washington Post, January 8, 2019, https://www.washingtonpost.com/politics/2019/live-updates/trump-white-house/live-fact-checking-andanalysis-of-president-trumps-immigration-speech/a-history-of-trumps-promises-that-mexico-would-pay-for-the-wall-which-it-refuses-to-do/

${ }^{26}$ Michael McGrath, "Beyond Distrust: When the Public Loses Faith in American Institutions," National Civic Review 106, no. 2 (Summer 2017), 47.

${ }^{27}$ Megan Brennan, “Americans Split on Whether Afghanistan War Was a Mistake,” July 26, 2021, https://news.gallup.com/ poll/352793/americans-split-whether-afghanistan-war-mistake.aspx

${ }^{28}$ Pew Research Center, “Americans' Views of Government: Low Trust, But Some Positive Performance Ratings,” September 14, 2020, https://www.pewresearch.org/politics/2020/09/14/americans-views-of-government-low-trust-but-some-positive-performanceratings/
} 
to them through online media, the decline in the support for the Vietnam War was a "reflection of being better informed about what the war was costing (e.g., via pictures of dead and wounded Americans)" which had never happened previously during an ongoing war. ${ }^{29}$

\section{Conclusion}

After considering the supporting questions, students will return to the larger question: What does 1968 mean to the creation of the current American identity? Students will make their case to the larger thematic question through a final paper or visual presentation. This process allows the students to demonstrate how they understand the connections and differences between 1968 and our current American identity. Students must demonstrate connections by utilizing primary source documents from 1968 and today to construct an argument regarding the legacy of 1968 with respect to equality, domestic politics, and foreign affairs. While the academic goal of this thematic unit is to give relevance to 1968 as a landmark year, the overreaching goal is to help the students gain connections with moments in history and establish long lasting connections with them as they investigate 1968's influence on their lives today. By designing a thematic unit and allowing students to explore history in this manner, the hope is that the students have gained a deeper understanding of how the American narrative is still a living part of the moments of years gone by.

\footnotetext{
${ }^{29}$ H. M. Schrieber, "Anti-War Demonstrations and American Public Opinion on the War in Vietnam," The British Journal of
} Sociology, 27, no. 2 (June 1976), 231. 